\title{
Total alkaline phosphatase activity in bottom sediments of Szmaragdowe lake in the city of Szczecin (North-West Poland)
}

\author{
Piotr Daniszewski \\ Department of Invertebrate Zoology and Limnology, Faculty of Biology, University of Szczecin, \\ 13 Wąska Street, 71-415 Szczecin, Poland \\ E-mail address: daniszewski73@gmail.com
}

\begin{abstract}
Level of activity alkaline phosphatase (APA) has an important impact on the chemical and biological processes taking place in the aquatic environment. APA belongs to a group of indicators, who tells us about the extent limitations to development of biomass in the tank water. Water of Szmaragdowe lake were the subjects of 2008-2012 (July - September). Total alkaline phosphatase activity was determined seven times a year in these environments. A study of seasonal fluctuations showed that a maximum total alkaline phosphatase activity, both in the bottom sediment, occurred in spring (May) and summer (July, August). Total alkaline phosphatase activity in the bottom sediment of Szmaragdowe lake over the five-year period of study oscillated between 764.1 to $7938.7 \mathrm{nmol}$ $\mathrm{PO}_{4} \cdot \mathrm{dm}^{-3} \cdot \mathrm{h}^{-1}$. In the littoral it ranged from 3107.4 to $7938.7 \mathrm{nmol} \mathrm{PO}_{4} \cdot \mathrm{dm}^{-3} \cdot \mathrm{h}{ }^{-1}$, and in sublittoral from 764.1 to $3429.5 \mathrm{nmol} \mathrm{PO}_{4} \cdot \mathrm{dm}^{-3} \cdot \mathrm{h}^{-1}$.
\end{abstract}

Keywords: total alkaline phosphatase activity; bottom sediment; Szmaragdowe lake

\section{INTRODUCTION}

Urbanization is the cause of many changes which is taking place in the environment, including those found in the catchment [3-7,11-17].

Phosphorous plays a key role in biological production and thereby in the eutrophication of the water environment [4-7,11,15-18,28-30]. One of the important processes impacting on the level of available mineral phosphorous is enzymatic hydrolysis of organic bonds of this element [11,14-17,19-26,29,30]. A majority of previous studies shows that alkaline phosphatase is chiefly responsible for the rate of organic phosphorous mineralization, both in the pelagic zone and in the bottom sediment of water bodies with $\mathrm{pH}>7$ [1-9,11-15,27,30]. However, some authors report, e.g. Yiyong [22], that abiotic factors can also play a part in the process. Jones [21] suggests that the level of phosphatase activity in the water is linked to the degree of lake trophicity. Whereas phosphatase activity in bottom sediment, according to Kobari and Taga [22], can indicate their enzymatic potential [18].

The assumption for this cycle of study was also to demonstrate the usefulness of the applied enzymatic test as a biological indicator of the degree of lake trophicity and possibly of progressing eutrophication of the analyzed water bodies. 


\section{EXPERIMENTAL}

Szczecin is situated in North-Western Poland, in the western part of West Pomeranian Voivodeship in the Polish-German border [31]. Szmaragdowe Lake - the origin of the artificial in the Beech Forest, formed 26 July 1925 as a result of the flooding of the mine's existing before the war. Explore color water owes its name (the effect of the content of calcium carbonate) [31]. Lake morphometric data: area - 4.5 ha, average depth $-8.2 \mathrm{~m}$, maximum depth - $15.8 \mathrm{~m}$ [31].

Littoral sediment was sampled with a Kajak core sampler with a surface of $20 \mathrm{~cm}^{2}$, while sublittoral sediment with Borucki apparatus with the surface of $225 \mathrm{~cm}^{2}$. Activity of that enzyme in bottom sediments was established in accordance with Tabatabai and Bremmer [29], using the aforementioned buffer solution. The study was conducted during 2008-2012.

The analyses were carried out 7 times a year (April, May, June, July, August, September and October), in three repetitions.

\section{RESULTS AND DISCUSSION}

Results of the General activity of the alkaline phosphatase in the Deep in bottom sediment of the Lake in Szmaragdowe are presented in tables 1 to 5.

Table 1. The total alkaline phosphatase activity in bottom sediment $\left(\mathrm{nmol} \mathrm{PO}_{4} \cdot \mathrm{dm}^{-3} \cdot \mathrm{h}^{-1}\right)$ in 2008 .

\begin{tabular}{|c|c|c|c|}
\hline S. $\mathbf{N}$. & Dates of analyses & \multirow{2}{*}{ Littoral } & \multirow{2}{*}{ Sublittora } \\
\hline \multicolumn{2}{|r|}{2008} & & \\
\hline 1. & April & 4231.2 & 1530.2 \\
\hline 2. & May & 4793.9 & 2328.7 \\
\hline 3. & June & 5649.1 & 3342.6 \\
\hline 4. & July & 7938.7 & 2961.0 \\
\hline 5. & August & 6869.2 & 2214.8 \\
\hline 6. & September & 5321.0 & 1183.1 \\
\hline 7. & October & 3794.2 & 652.8 \\
\hline
\end{tabular}


Table 2. The total alkaline phosphatase activity in bottom sediment $\left(\mathrm{nmol} \mathrm{PO} \cdot \mathrm{dm}^{-3} \cdot \mathrm{h}^{-1}\right)$ in 2009 .

\begin{tabular}{|c|c|c|c|}
\hline S. N. & Dates of analyses & \multirow{3}{*}{$\begin{array}{c}\text { Littoral } \\
4532.8\end{array}$} & \multirow{3}{*}{$\begin{array}{c}\text { Sublittoral } \\
1725.4\end{array}$} \\
\hline \multicolumn{2}{|r|}{2009} & & \\
\hline 1. & April & & \\
\hline 2. & May & 5091.4 & 2159.7 \\
\hline 3. & June & 5373.6 & 2767.0 \\
\hline 4. & July & 7383.3 & 3290.3 \\
\hline 5. & August & 6936.8 & 2069.6 \\
\hline 6. & September & 5259.5 & 1436.8 \\
\hline 7. & October & 3107.4 & 764.1 \\
\hline
\end{tabular}

Table 3. The total alkaline phosphatase activity in bottom sediment $\left(\right.$ nmol $\left.\mathrm{PO}_{4} \cdot \mathrm{dm}^{-3} \cdot \mathrm{h}^{-1}\right)$ in 2010 .

\begin{tabular}{|c|c|c|c|}
\hline S. $\mathbf{N}$. & Dates of analyses & \multirow{2}{*}{ Littoral } & \multirow{2}{*}{ Sublittoral } \\
\hline \multicolumn{2}{|r|}{2010} & & \\
\hline 1. & April & 4081.3 & 1937.5 \\
\hline 2. & May & 4520.6 & 2541.1 \\
\hline 3. & June & 5139.1 & 3116.9 \\
\hline 4. & July & 7218.5 & 3639.4 \\
\hline 5. & August & 6730.3 & 1867.6 \\
\hline 6. & September & 4703.8 & 1714.9 \\
\hline 7. & October & 3240.2 & 821.7 \\
\hline
\end{tabular}

The results presented in in Tables 1 to 5 demonstrate that total alkaline phosphatase activity in the bottom sediment of Szmaragdowe lake over the five-year period of study oscillated between 764.1 to $7938.7 \mathrm{nmol} \mathrm{PO}_{4} \cdot \mathrm{dm}^{-3} \cdot \mathrm{h}^{-1}$.

In the littoral it ranged from 3107.4 to $7938.7 \mathrm{nmol} \mathrm{PO}_{4} \cdot \mathrm{dm}^{-3} \cdot \mathrm{h}^{-1}$, and in sublittoral from 764.1 to $3429.5 \mathrm{nmol} \mathrm{PO}_{4} \cdot \mathrm{dm}^{-3} \cdot \mathrm{h}^{-1}$. 
Table 4. The total alkaline phosphatase activity in bottom sediment $\left(\mathrm{nmol} \mathrm{PO}_{4} \cdot \mathrm{dm}^{-3} \cdot \mathrm{h}^{-1}\right)$ in 2011 .

\begin{tabular}{|c|c|c|c|}
\hline S. $\mathbf{N}$. & Dates of analyses & \multirow{3}{*}{$\begin{array}{c}\text { Littoral } \\
4157.8\end{array}$} & \multirow{3}{*}{$\begin{array}{c}\text { Sublittoral } \\
2189.5\end{array}$} \\
\hline \multicolumn{2}{|r|}{2011} & & \\
\hline 1. & April & & \\
\hline 2. & May & 4891.2 & 2785.8 \\
\hline 3. & June & 5039.0 & 2974.2 \\
\hline 4. & July & 6839.5 & 3429.5 \\
\hline 5. & August & 6105.3 & 2708.3 \\
\hline 6. & September & 4183.9 & 1748.5 \\
\hline 7. & October & 3058.7 & 1129.3 \\
\hline
\end{tabular}

Table 5. The total alkaline phosphatase activity in bottom sediment $\left(\right.$ nmol $\left.\mathrm{PO}_{4} \cdot \mathrm{dm}^{-3} \cdot \mathrm{h}^{-1}\right)$ in 2012 .

\begin{tabular}{|c|c|c|c|}
\hline S. $\mathbf{N}$. & Dates of analyses & \multirow{2}{*}{ Littoral } & \multirow{2}{*}{ Sublittoral } \\
\hline \multicolumn{2}{|r|}{2012} & & \\
\hline 1. & April & 4387.5 & 2029.3 \\
\hline 2. & May & 5073.0 & 2364.9 \\
\hline 3. & June & 5704.7 & 3284.6 \\
\hline 4. & July & 6471.3 & 3690.7 \\
\hline 5. & August & 7053.9 & 2174.2 \\
\hline 6. & September & 4274.1 & 1619.5 \\
\hline 7. & October & 3079.0 & 779.1 \\
\hline
\end{tabular}

Total alkaline phosphatase activity in the bottom sediments of the analyzed water body was subject to seasonal oscillations. Irrespectively of the state of the environment aggregation, they typically demonstrated similar course in both analyzed zones. An average value of two years of total alkaline phosphatase activity of the littoral deposits ranged at a higher level than that of the sublittoral. The observed phenomena was accompanied by more numerous occurrence of various groups of bacteria and saprophytic fungi in the sublittoral 
zone. It would indicate a closer relationship between phosphatase activity of the sediments and heterotrophic microorganisms growth [11-18]. Both in the bottom sediments a higher level of the activity was determined in spring (May) and in full summer period (July and August).

In the pelagic zone a maximum of total alkaline phosphatase activity occurred in July, which is consistent with the results of research the author of this paper conducted on other lakes. What is noteworthy is the fact that higher values of the studied activity were not always accompanied by larger number of bacteria and saprophytic fungi [18, 24, 25], which would confirm the importance of algae affecting its level. Whereas in the bottom sediment an increase in total alkaline phosphatase activity in July and August clearly showed a link between the number of heterotrophic bacteria, which most probably results from an influx into the sediments of phytoplankton, dying after spring blooms.

\section{CONCLUSIONS}

1. Total alkaline phosphatase activity in Szmaragdowe lake in bottom sediment was the highest in the top layer of the littoral.

2. Total alkaline phosphatase activity both in the bottom sediment was subject to seasonal changes, and their course was of similar nature. A maximum activity was observed in both environments in the spring (May) and in the summer (July and August).

\section{References}

[1] Chróst R. J., Siuda W., Halemejko G. Z., Arch. Hydrobiol. Suppl. 70(1) (1984) 1-32.

[2] Chróst R. J., Siuda W., Limnol. Oceanogr. 31 (1986) 662-667.

[3] Daniszewski P., International Letters of Chemistry, Physics and Astronomy 1 (2012) 13-16.

[4] Daniszewski P., International Letters of Chemistry, Physics and Astronomy 2 (2012) $35-41$.

[5] Daniszewski P., International Letters of Chemistry, Physics and Astronomy 2 (2012) 42-45.

[6] Daniszewski P., International Letters of Chemistry, Physics and Astronomy 2 (2012) 46-52.

[7] Daniszewski P., International Letters of Chemistry, Physics and Astronomy 4 (2012) 119-124.

[8] Daniszewski P., International Letters of Chemistry, Physics and Astronomy 5 (2012) 72-79.

[9] Daniszewski P., International Letters of Chemistry, Physics and Astronomy 5 (2012) 80-87.

[10] Daniszewski P., International Letters of Chemistry, Physics and Astronomy 1 (2012) 13-16. 
[11] Daniszewski P., International Letters of Chemistry, Physics and Astronomy 2 (2012) 42-45.

[12] Daniszewski P., International Letters of Chemistry, Physics and Astronomy 3 (2012) 80-85.

[13] Daniszewski P., International Letters of Chemistry, Physics and Astronomy 4 (2012) 119-124.

[14] Daniszewski P., International Letters of Chemistry, Physics and Astronomy 7(1) (2013) 60-66.

[15] Daniszewski P., International Letters of Chemistry, Physics and Astronomy 7(1) (2013) $67-72$.

[16] Daniszewski P., International Letters of Chemistry, Physics and Astronomy 8(1) (2013) 87-93.

[17] Daniszewski P., Journal of Ecological Engineering 14(2) (2013) 74-78.

[18] Furczak J., Acta Agrophysica 4(2) (2000) 291-299.

[19] Górniak A., Composition of the organic matter in lakes bottom sediments. Procc. IHSS Ins. Meeting, Barii, ed. Senesi N., Miano T.M., Elsevier Publisher, Amsterdam, 1993.

[20] Jansson M., Olssonh., Pettersson K., Hydrobiol. 170 (1988) 157-175.

[21] Jones J. G., J. Ecol. 60 (1972) 777-791.

[22] Kobari H., Taga N., Deep-Sea Res. 26A (1979) 799-808.

[23] Korniłłowicz T., Acta Mycol. 29 (1994) 23-31.

[24] Korniłłowicz T., Acta Mycol. 29 (1994) 159-168.

[25] Misztal M., Smal H., Studia Ośr. Dok. Fizjograf. PAN, Oddział w Krakowie. 19 (1991) 193- 207.

[26] Sayler G. S., Puziss M., Silver M., Appl. Environ. Microbiol. 38 (1979) 922-927.

[27] Schindler D.W., Limnol. Oceanogr. 23 (1978) 478-486.

[28] Siuda W., Pol. Arch. Hydrobiol. 31 (1984) 207-233.

[29] Tabatabai M. A., Bremner J. M., Soil Biol. Biochem. 1 (1969) 301-307.

[30] Yiyong Z. H., Hydrobiol. 335 (1996) 55-62.

[31] Janczak J., Atlas Polish Lakes (1996) 92-95. 